\title{
Technosociality in the daily lives of primary care professionals and health promotion: scoping review
}

\author{
A tecnossocialidade no cotidiano de profissionais da atenção primária \\ e promoção da saúde: scoping review
}

Tamires Carolina Silva', Andresa Guerra de Carvalho', Adriana Dutra Thol|2, Maria Aurora

Rodriguez Borrego ${ }^{\mathbf{3}}$, Pablo Jesús López Soto ${ }^{3}$, Selma Maria da Fonseca Viegas' ${ }^{\mathbf{1}}$

DOI: $10.1590 / 0103-11042021131171$

\begin{abstract}
This study aimed to map the available evidence on technosociality in the daily lives of primary care professionals to promote the health of people/families. This is a scoping review based on the Joanna Briggs Institute and Prisma-ScR. The PCC strategy (participants, concept and context) was used. The sample comprises 25 articles. The predominant language was English, the year, 2018, the strength of evidence, 5 and the quality of evidence, high and moderate. Technologies are part of the daily life of PHC professionals and include health control, curative and medication measures. They are sources of communication between professionals and professionals and users. For the use of technologies, it is essential that professionals are trained, using evidence-based practices to achieve the objectives in view of the needs of each one. The use of technologies to promote the health of people/families represents a technological innovation in Primary Health Care, with the possibility of impacting health conditions and promoting healthier life choices.
\end{abstract}

KEYWORDS Technology. Primary Health Care. Mobile applications. Social networking. Health promotion.

1 Universidade Federal de São João del-Rei (UFSJ) Divinópolis (MG), Brasil. selmaviegas@ufsj.edu.br

2 Universidade Federal de Santa Catarina (UFSC) Florianópolis (SC), Brasil.

3 Universidad de Córdoba, Instituto Maimónides de Investigación Biomédica de Córdoba, Hospital Universitário Reina Sofía de Córdoba - Córdoba, España.

RESUMO Este estudo teve por objetivo mapear a evidência disponível sobre a tecnossocialidade no cotidiano de profissionais da atenção primária para a promoção da saúde de pessoas/famílias. Trata-se de uma scoping review fundamentada no Joanna Briggs Institute e no Prisma-ScR. Foi utilizada a estratégia PCC (participants, concept e context). A amostra compõe 25 artigos. $O$ idioma predominante foi o inglês, o ano foi 2018, a força de evidência 5 e a qualidade de evidência alta e moderada. As tecnologias fazem parte do cotidiano dos profissionais da APS e abrangem medidas de controle da saúde, curativas e medicamentosas. São fontes de comunicação entre profissionais e profissionais e usuários. Para o uso de tecnologias, é imprescindível que os profissionais estejam capacitados, utilizando práticas baseadas em evidências para alcançar os objetivos perante as necessidades de cada um. O uso de tecnologias para a promoção da saúde de pessoas/ famílias representa uma inovação tecnológica na Atenção Primária à Saúde, com possibilidade de impacto nas condições de saúde e promoção de escolhas mais saudáveis de vida.

PALAVRAS-CHAVE Tecnologia. Atenção Primária à Saúde. Aplicativos móveis. Rede social. Promoção da saúde. 


\section{Introduction}

Technosociality, according to Michel Maffesoli, is a way of socially communicating and interacting that postpone itself to technology, represented by the internet and its tools, which have become essential in everyday life in post-modern times ${ }^{\mathbf{1 - 2}}$. Postmodern technology can be considered part of the re-enchantment of the world ${ }^{3}$ by the accelerated technosocial process of virtual approach to human interactions.

Communication in social media tends to favor listening and vocalization of the different groups involved $\mathbf{4}^{\mathbf{4}}$, contributing to the process of making public what was private'. In the health area, the use of technology-based tools in Primary Health Care (PHC) has become increasingly frequent ${ }^{5-6}$. Health professionals working in $\mathrm{PHC}$ can use digital technologies to promote actions to prevent risks and injuries and health education and promotion ${ }^{7}$.

Regarding health promotion, social networks such as WhatsApp, Facebook and Twitter can be used to achieve unique strategies to optimize healthier life choices ${ }^{8}$, which contributes to the construction of actions that make it possible to respond to social needs in health'.

However, the introduction and use of digital technologies in PHC has caused changes and impacts in the daily work of health professionals that deserve to be investigated, considering that the various interactive means of communication, especially the internet, represent exceptional mechanisms ${ }^{3}$. This scoping review is justified due to the fact that technosociality in the daily life of PHC professionals for the promotion of people/families' health is still little explored $5,6,8$. Therefore, the following question arises: what is the state of the art on the use of health technologies and virtual social networks by PHC health professionals to promote the health of people/families.

This study aimed to map the available evidence on the use of health technologies and virtual social networks in the daily lives of $\mathrm{PHC}$ professionals and the promotion of health for people/families.

\section{Material and methods}

It is a scoping review based on the Joanna Briggs Institute and on the recommendations of the Preferred Reporting Items for Systematic Reviews and Meta-Analyses (Prisma-ScR) ${ }^{10}$. The research protocol was registered in the Open Science Framework (https://osf.io/hyv8b/). It shows a comprehensive and impartial synthesis of relevant studies that address the use of technosociality in the daily life of $\mathrm{PHC}$ professionals to promote the health of people/families in post-modernity.

This type of review is characterized by presenting a broad topic approach and very specific research questions, making it possible for researchers to carry out the quality assessment of the included studies. Thus, through scoping review, it is possible to map evidence on certain topics, enabling concepts, dimension, scope and nature of studies to be explored, condensing and publishing the synthesized results, as well as surveying gaps about the studies available in databases ${ }^{10-12}$.

This scoping review was developed following eight steps, starting with the formulation of the review question; definition of inclusion and exclusion criteria; location of studies through search in databases; selection of studies; evaluation of the quality of studies; data extraction; data analysis; synthesis of relevant data ${ }^{13}$. To classify the quality of evidence in the studies, the Grading of Recommendations Assessment, Development and Evaluation (Grade) was considered, in order to obtain transparency and simplicity, considering four levels of evidence quality: high, moderate, low and very low ${ }^{\mathbf{1 4}}$.

The research considered the time span from 2016 to 2019. The civil mark of the internet in Brazil was given by Law No. 12,965, of 
April 23, 2014, which establishes principles, guarantees, rights and duties for the use of the internet in Brazil ${ }^{4}$, and by Decree No. 8,771, of May 11, 2016, which rules for various topics dealt with in Law No. 12,965/2014 and which depended on regulation after two years of discussion ${ }^{15}$. The search was performed in PubMed (National Institutes of Health), SciELO (Scientific Electronic Library Online), Scopus, Web of Science, Lilacs (Latin American and Caribbean Health Sciences), Cinahl (Cumulative Index to Nursing and Allied Health Literature) and Cochrane (Cochrane Library).

Inclusion criteria were full articles available and empirical and theoretical studies, in Portuguese, English and Spanish. Using the Participants, Concept and Context (PCC) strategy, this scoping review included studies that: a) refer to health professionals working in PHC; b) consider the concept and use of technologies; c) cover the context of impact on health promotion. Studies in project phases, which did not clearly present the results and whose focus did not correspond to the proposed theme, were excluded from the research.

The search was carried out from January to April 2020, using the following Boolean descriptors and operators: "Primary Health Care" AND "Technology" AND "Health Promotion"; "Primary Health Care" AND "Social Networking" AND "Health Promotion"; "Primary Health Care" AND "Mobile applications" AND "Health Promotion"; "Primary Health Care" AND "Technology" AND "Health Behavior"; "Primary Health Care" AND "Mobile applications"; "Primary Health Care" AND "Health Promotion"; "Primary Health Care" AND "Technology"; "Technology" AND "Health Behavior".

Data selection was structured according to the following steps: in the 1st step, the Boolean descriptors and operators used in the study were defined, as well as the search databases: PubMed, Scopus, SciELO, Web of
Science, Lilacs, Cinahl and Cochrane. In the 2nd stage, there was the application of filters: text available in a free and complete way; languages - English, Portuguese and Spanish; year -2016 to 2019 on the defined bases. To find out if the articles corresponded to the research question, the titles and descriptors were read. In the 3 rd stage, the abstract, introduction and conclusion of each article was read, in order to verify its relevance for the study and whether the inclusion and exclusion criteria were met. Finally, in the 4 th stage, the pre-selected articles were read in full by the researchers, with the aim of verifying with greater precision their relevance to the study and whether the inclusion and exclusion criteria were met. We then proceeded to extract relevant data for further analysis, taking into account the previously established protocol.

The reading of the full articles and application of the inclusion and exclusion criteria enabled the data extraction. The articles were analyzed in terms of quality and categorized by degree of recommendation and level of evidence, according to the classification developed by the Evidence-Based Practice (EBP).

EBP and evidence-based health care embrace the same concepts and principles as evidence-based medicine and are employed by various professionals and in different health contexts. EBP has been conceptualized as the conscious, judicious and explicit use of the best and most current research evidence in making clinical decisions about individual patient care. This hierarchy guides the criteria for classifying evidence levels for different types of studies ${ }^{16-18}$.

Evidence can be characterized as something that provides proof for decision making, encompassing study results and consensus of recognized experts ${ }^{19}$.

The strength of evidence can be classified into five distinct levels: level 1 , when it is strong evidence from, at least, a systematic review of multiple controlled, randomized, 
well-designed studies; level 2, when there is strong evidence from at least one randomized, controlled study, of appropriate design and adequate size; level 3 , when it is referring to evidence from well-designed studies without randomization, single group pre and postcohort, time series or paired case-control; level 4, when related to evidence from studies, of non-experimental orders, carried out in research centers or groups; and level 5 , when it covers opinions of respected authorities, based on clinical evidence, reports from expert committees or descriptive studies ${ }^{20}$.

The process of identification, selection, eligibility and inclusion of studies in this scoping review can be seen in figure 1 .

Figure 1. Process of identification, selection, eligibility and inclusion of scoping review studies, 2020

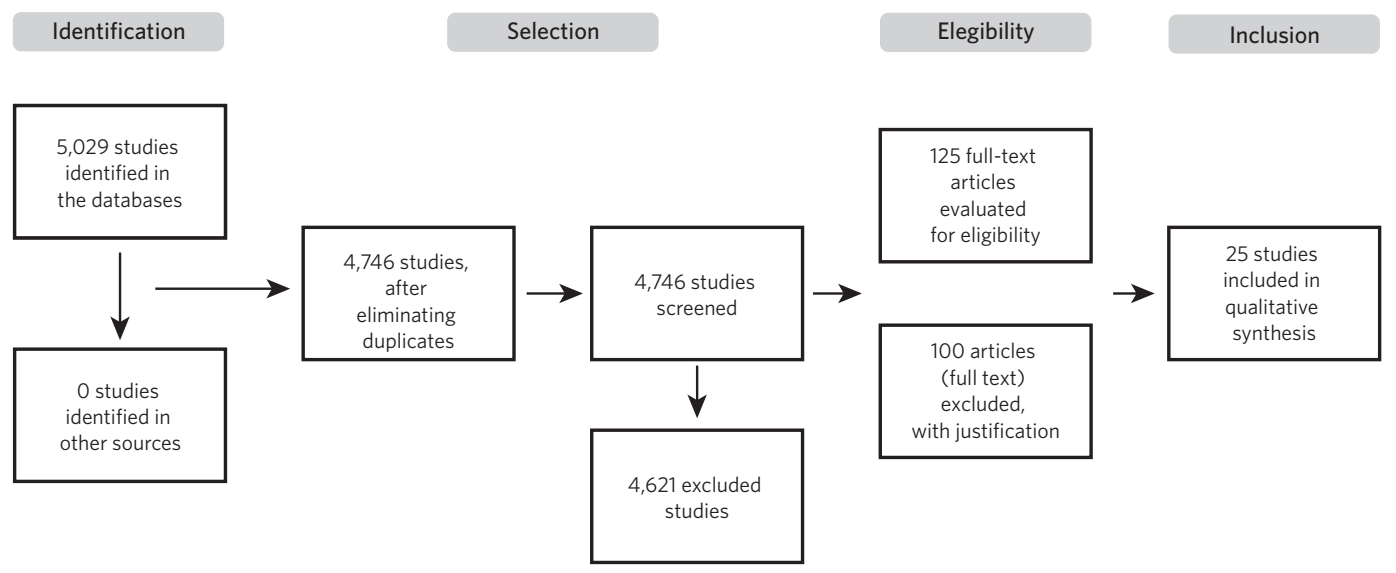

Source: Self elaborated.

\section{Results}

The search in the databases was refined through filters: free and complete text available; languages in English, Portuguese and Spanish; publication date between 2016 and 2019. A total of 5,029 studies were obtained, of which 283 were excluded because they were duplicates, resulting in 4,746 documents. After reading the abstract, introduction and conclusion of each article to identify its relevance for the research and if it met the inclusion or exclusion criteria, arriving at a total of 125 articles, from the PubMed (28), SciELO (18), Scopus (21), Web of Science (11), Cinahl (36) and Cochrane (11). Subsequently, the articles were read in full and, at this stage, studies with no consistency with the theme, different sample populations of $\mathrm{PHC}$ professionals, studies in the design phase or without clear results were excluded, obtaining, for this scoping review, a final sample of 25 articles.

The years of publication spanned from 2016 to 2019, with 2018 being the most representative year, with 11 articles. The predominant language was English (22), followed by Portuguese (02) and Spanish (01). These studies were carried out in Brazil (05), Spain (03), Sweden (03), Ireland (02), USA (02), Africa (01), China (01), Norway (01), United Kingdom (01), Australia (01), Poland (01), Netherlands (01) and Canada (01). Two studies did not report the location where they were carried out. 
Considering the strength of evidence among the levels, the one with the highest prevalence was level 5 (10), subsequent to level 2 (05), level 3 (04), level 1 (04) and level 4 (02).

As for the quality of evidence from the Grade system, among its levels, the ones that presented the highest prevalence were high quality (09) and moderate quality (09), subsequent to low quality (05) and very low quality (02).

Considering the participants - health professionals working in $\mathrm{PHC}$, the concept - the use of technologies, context - the impact on health promotion, the results obtained can be seen in table 1.

Table 1. Presentation of articles according to title, year of publication, database, type of study, level of evidence, objective and final conclusions/ recommendations, 2016 to 2019

\begin{tabular}{|c|c|c|c|}
\hline Reference (year) & $\begin{array}{l}\text { Article/ Type of study/ Database/ } \\
\text { Level of evidence/ Sample }\end{array}$ & Study objective & Conclusions \\
\hline $\begin{array}{l}\text { Ramsey et al.5 } \\
\text { (2019) }\end{array}$ & $\begin{array}{l}\text { Technology-Based Alcohol Inter- } \\
\text { ventions in Primary Care: System- } \\
\text { atic Review } \\
\text { Systematic Review } \\
\text { PubMed } \\
\text { Level of Evidence: } 1 \\
\text { Sample: } 42 \text { studies }\end{array}$ & $\begin{array}{l}\text { Review recent literature on the } \\
\text { use of technology to provide, } \\
\text { enhance or support the imple- } \\
\text { mentation of interventions } \\
\text { related to alcohol use by PHC } \\
\text { users. }\end{array}$ & $\begin{array}{l}\text { - Evidences the use of technological platforms, comput- } \\
\text { er, web or cell phone for actions to support the change } \\
\text { in the behavior of alcohol users; } \\
\text { - The use of technologies by professionals is efficient to } \\
\text { promote interventions related to alcohol use. }\end{array}$ \\
\hline $\begin{array}{l}\text { Jong et al.6 } \\
(2017)\end{array}$ & $\begin{array}{l}\text { The challenge of involving elderly } \\
\text { patients in primary care using an } \\
\text { electronic communication tool } \\
\text { with their professionals: a mixed } \\
\text { methods study } \\
\text { Study of mixed methods, with a } \\
\text { quantitative approach } \\
\text { Scopus } \\
\text { Level of Evidence: } 3 \\
\text { Sample: } 22 \text { patients }\end{array}$ & $\begin{array}{l}\text { Examine whether an electronic } \\
\text { communication tool (Congredi) } \\
\text { designed for professionals, } \\
\text { including a care plan and se- } \\
\text { cure email, is usable for patient } \\
\text { systems and what their experi- } \\
\text { ences are. }\end{array}$ & $\begin{array}{l}\text { - Congredi technology aims the electronic communica- } \\
\text { tion with other professionals, informal caregivers and } \\
\text { patients; } \\
\text { - The use of this tool allows sharing and drawing up the } \\
\text { care plan for the patient; } \\
\text { - Patient and professionals communicate using technol- } \\
\text { ogy through the patient portal, which allows the patient } \\
\text { to view the care plan; } \\
\text { - Barriers: not all professionals were linked to Congredi, } \\
\text { and when informal caregivers did not receive feedback } \\
\text { from professionals, there was no incentive for them to } \\
\text { use the tool later. }\end{array}$ \\
\hline $\begin{array}{l}\text { Berman et al. } \\
(2018)\end{array}$ & $\begin{array}{l}\text { Clinician experiences of healthy } \\
\text { lifestyle promotion and perceptions } \\
\text { of digital interventions as } \\
\text { complementary tools for lifestyle } \\
\text { behavior change in primary care } \\
\text { Qualitative study } \\
\text { Scopus } \\
\text { Level of Evidence: } 5 \\
\text { Sample: } 46 \text { health professionals }\end{array}$ & $\begin{array}{l}\text { Explore the perceptions of cli- } \\
\text { nicians working in PHC about } \\
\text { promoting a healthy lifestyle, } \\
\text { with or without screening and } \\
\text { digital intervention. }\end{array}$ & $\begin{array}{l}\text { - Working with health promotion using digital interven- } \\
\text { tions, considered as a positive challenge; } \\
\text { - The initial use of digital inventions can change the } \\
\text { practice of health professionals; } \\
\text { - The article does not show the type of technology } \\
\text { used to carry out digital interventions in favor of health } \\
\text { promotion; } \\
\text { - It is necessary to maintain a balanced view of digi- } \\
\text { tal interventions, declaring their role in promoting a } \\
\text { healthy lifestyle. }\end{array}$ \\
\hline $\begin{array}{l}\text { Marin-Gomez et } \\
\text { al.8 (2018) }\end{array}$ & $\begin{array}{l}\text { Social Networking App Use Among } \\
\text { Primary Health Care Professionals: } \\
\text { Web-Based Cross-Sectional Survey } \\
\text { Cross-sectional, descriptive study } \\
\text { PubMed } \\
\text { Level of Evidence: } 5 \\
\text { Sample: } 483 \text { health professionals }\end{array}$ & $\begin{array}{l}\text { Explore the use of social } \\
\text { networking apps for mobile } \\
\text { phones among PHC profes- } \\
\text { sionals for work-related pur- } \\
\text { poses. }\end{array}$ & $\begin{array}{l}\text { - The use of social networking applications such as } \\
\text { Facebook, WhatsApp, Twitter, Instagram and others, by } \\
\text { health professionals is aimed at communication actions } \\
\text { between professionals, clinical or drug consultations } \\
\text { and, mainly, for professional development, as well as } \\
\text { actions of health promotion. }\end{array}$ \\
\hline
\end{tabular}


Table 1. (cont.)

\begin{tabular}{|c|c|c|c|}
\hline Reference (year) & $\begin{array}{l}\text { Article/ Type of study/ Database/ } \\
\text { Level of evidence/ Sample }\end{array}$ & Study objective & Conclusions \\
\hline $\begin{array}{l}\text { Oliver-Mora \& } \\
\text { Iñiguez-Rueda21 } \\
\text { (2017) }\end{array}$ & $\begin{array}{l}\text { El uso de las tecnologías de la } \\
\text { información y la comunicación (TIC) } \\
\text { en los centros de salud: la visión de los } \\
\text { profesionales en Cataluña, España } \\
\text { Experience reports } \\
\text { Scielo } \\
\text { Level of Evidence: } 5 \\
\text { Sample: } 9 \text { health professionals }\end{array}$ & $\begin{array}{l}\text { Identify experiences using } \\
\text { information and communica- } \\
\text { tion technologies capable of } \\
\text { improving the public manage- } \\
\text { ment of Health Centers in } \\
\text { Catalonia (Spain) and which } \\
\text { were promoted 'from the bot- } \\
\text { tom up' by PHC professionals. }\end{array}$ & $\begin{array}{l}\text { - The use of virtual communication, such as blogs, can } \\
\text { be seen as a tool for both health promotion and health } \\
\text { education, as well as for promoting patient involvement } \\
\text { and awareness of their health status; } \\
\text { - The use of these technologies can make it possible for } \\
\text { patients to freely express their discomfort and dialogue } \\
\text { with health professionals; } \\
\text { - Patient blogs are the result of the desire to open new } \\
\text { avenues for communication between healthcare profes- } \\
\text { sionals and patients. }\end{array}$ \\
\hline
\end{tabular}

Plessis et al.22 Implementation of the Road-to-

(2017) Health-Booklet health promotion messages at primary health care facilities, Western Cape Province, South Africa

Cross-sectional descriptive study Cochrane

Level of Evidence: 5

Sample: 5,193 participants

Mastellos et al.25 Feasibility and acceptability of (2016) TRANSFoRm to improve clinical trial recruitment in primary care Randomized Controlled Study Cinnahl

Level of Evidence: 2

Sample: 5 doctors and 10 patients

Lofters et al. 26 (2016)
Facebook as a tool for communication, collaboration, and informal knowledge exchange among members of a multisite family health team
Descriptive study scopus
Level of Evidence: 5
Sample: 26 health professionals

Keyworth et al.27 What maximizes the effectiveness (2018) and implementation of technologybased interventions to support healthcare professional practice? A systematic literature review PubMed

Level of Evidence: 1

Sample: 69 studies

Smailhodzic et al. 28 (2016)
Assess the implementation of health promotion messages and identify barriers faced.

Assess the acceptability and feasibility of TRANSFoRm to improve clinical trial recruitment in $\mathrm{PHC}$.

Implement and evaluate a private Facebook group for members of an Ontario, Canada family health team to facilitate improved communication and collaboration.

Identify interventions with a successful technological component to change professional practice; determine whether interventions are theory-based; examine barriers and enablers for successful implementation.

Provide an overview of the existing literature on the effects of patients' use of social media for health reasons and its relationship to the actions of health professionals.
- Although the study investigates the use of mobile technologies by health professionals for health promotion actions related to infant and child feeding, they have not yet been implemented in the investigated PHC teams. It is noted that professionals still use posters, pamphlets and educational material for this purpose.

- The use of TRANSFoRm technology enables data collection, patient identification, pre-screening and monitoring of users;

- The medical acceptability of the TRANSFoRM tool was positive, as well as by the patients, due to its simple and easy-to-use application.

- The use of the Facebook private group aimed at communication between the team's professionals; - Professionals show concern for the patient's privacy and that its use can increase the workload.

- The use of technology to support change in the professional's health practices aimed at communication actions between them, interventions and support for decision-making;

- It proved to be effective in changing professionals practices, raising the confidence of professionals for decision-making and care management;

- Barriers faced: increased workload, insufficient access to information technology resources and software updates, causing limitations in computer performance.

- The use of social media facilitates health communication with patients and between professionals; - It can encourage more equal communication, a more harmonious relationship, greater exchange of informawith healthcare professionals Literature systematic Review PubMed

Level of Evidence: 1

Sample: 22 articles tion with doctors, but less than ideal personal interaction between the patient/professional. 
Table 1. (cont.)

\begin{tabular}{|c|c|}
\hline Reference (year) & $\begin{array}{l}\text { Article/ Type of study/ Database/ } \\
\text { Level of evidence/ Sample }\end{array}$ \\
\hline $\begin{array}{l}\text { Cavalcante et al. }{ }^{\mathbf{2 9}} \\
(2018)\end{array}$ & $\begin{array}{l}\text { Diffusion of the technological } \\
\text { innovation e-sus ab: acceptance or } \\
\text { rejection? } \\
\text { Study of unique case, holistic, of } \\
\text { qualitative approach } \\
\text { PubMed } \\
\text { Level of Evidence: } 3 \\
\text { Sample: } 14 \text { participants }\end{array}$ \\
\hline
\end{tabular}

Daltro et al.30

(2017)

Bernardes et al. ${ }^{31}$ (2019)

Glynn et al.32 (2018)

\section{Study objective}

To analyze the diffusion of technological innovation 'eSUS AB strategy' in a family health team in western Minas Gerais.

Level of Evidence: 3

Aceitação e uso de tecnologias móveis de informação pelos agentes comunitários de saúde de Sapeaçu Exploratory and descriptive, with a quantitative approach Scielo Level of Evidence: 5 Sample: 23 community health agents

Facebook como Ferramenta Pedagógica em Saúde Coletiva: Integrando Formação Médica e Educação em Saúde

Experience report

Scielo

Level of Evidence: 4

Sample: 144 medical interns
Analyze the conditioning factors for the acceptance and use of mobile technologies (tablets) by community health agents in the municipality of Sapeaçu, Bahia, Brazil.

Report the experience of using a Facebook page to promote health education.

\section{Conclusions}

- The use of e-SUS AB technology enables data collection and recording, not involving health promotion actions;

- The implementation of technology has shown situations that increase its rejection: need for administrative reorganization of work, manual re-registration of several files, difficulty for professionals to extract reports, misunderstandings related to codes used in systems and software;

- Rapid and constant changes in the instruments used for data collection make access to information more difficult.

- The use of mobile technology (tablet) by community health agents is aimed at recording data;

- Even with the difficulties encountered, the incorporation of technology at the regional level was considered favorable. The conditioning factors for acceptance and use were the Community Health Agents' little previous experience with similar technologies and insufficient training in the use of the equipment;

- Weaknesses are the concomitance of manual and computerized records and the relative delay in transmitting the collected data.

- The use of Facebook by medical interns is aimed at actions for health education and promotion, preventing risks and injuries, directed at the community in general; - Among the topics highlighted on the Facebook page are the consequences of sedentary lifestyle, sleep deprivation, self-care, importance of physical exercise, combating suicide, fibromyalgia, early screening for cervical and prostate cancer, antivaccine movement, dengue epidemic in Brazil, prevention of prematurity, fight against Acquired Immunodeficiency Syndrome (AIDS) and anxiety disorder, in addition to promoting a blood donation campaign;

- The use of technology proved to be efficient for dissemination in health and as a powerful pedagogical tool for health education.

Conduct a theoretically informed analysis, using the theory of normalization processes, of possible barriers and levers for implementing a mobile health intrvation to promote physical activity in PHC.
- The use of the SmartMove app is intended to promote physical activities;

- It was observed that the application was well accepted by users, as there was an incentive to exercise;

- Professionals were concerned about whether they would be able to encourage the use of the application and whether users would know how to use it. 
Table 1. (cont.)

\begin{tabular}{|c|c|}
\hline Reference (year) & $\begin{array}{l}\text { Article/ Type of study/ Database/ } \\
\text { Level of evidence/ Sample }\end{array}$ \\
\hline $\begin{array}{l}\text { Bonn et al.33 } \\
(2018)\end{array}$ & $\begin{array}{l}\text { App-technology to increase } \\
\text { physical activity among patients } \\
\text { with diabetes type } 2 \text { - the DiaCert- } \\
\text { study, a randomized controlled trial } \\
\text { Randomized Controlled Study } \\
\text { Web of Science } \\
\text { Level of Evidence: } 2 \\
\text { Sample: } 200 \text { patients }\end{array}$ \\
\hline $\begin{array}{l}\text { Morrissey et al. }{ }^{\mathbf{3 4}} \\
(2018)\end{array}$ & $\begin{array}{l}\text { New self-management technolo- } \\
\text { gies for the treatment of hyperten- } \\
\text { sion: general practitioners' perspec- } \\
\text { tives } \\
\text { Qualitative research } \\
\text { PubMed } \\
\text { Level of Evidence: } 5 \\
\text { Sample: } 10 \text { general practitioners }\end{array}$ \\
\hline
\end{tabular}

Recio-Rodriguez ${ }^{35}$ The Effectiveness of a Smartphone (2018)

Wang et al. ${ }^{36}$ (2017)

Pinto \& Rocha ${ }^{37}$ (2016)

the Intakes of Macro and Micronutrients in Primary Care: A Randomized Controlled Trial. The EVIDENT II Study Randomized Controlled Study Scopus Level of Evidence: 2 Sample: 833 individuals

Evaluation of a WeChat-based dementia-specific training program for nurses in primary care settings: A randomized controlled trial Randomized Controlled Study Cochrane Level of Evidence: 2 Sample: 101 nurses

Innovations in Primary Health care: the use of communications

\section{Study objective}

Evaluate the effect of a physical activity intervention using a smartphone app on patients with type 2 diabetes.

Explore general practitioner perspectives on self-management technology to support medication adherence and blood pressure control in patients with hypertension.

Evaluate the long-term (12 months) effectiveness of adding a diet smartphone app. technology and information tools to support local management Descriptive Studies PubMed Level of Evidence: 5 Sample: 16 Observatories of Information Technology and Communications in Health - OTICS Network in Rio de Janeiro.

Determine whether a demenwhich incorporates WeChatbased learning interactions, could improve knowledge and attitudes, meeting nurses' intentions to make changes to achieve early detection and a timely diagnosis of dementia.

Describe the results obtained with the implementation of Local Networks of Observatories by the Municipal Health Department of Rio de Janeiro, covering ten areas of health planning in the city.

\section{Conclusions}

- The use of the DiaCert smartphone app is aimed at monitoring physical activity performed by patients;

- The app encourages patients to adopt healthier habits, such as daily physical exercise;

- This technology can be used as a new data sharing solution between patients and healthcare professionals.

- Using wireless apps or blood pressure monitors via smartphone can increase the amount of data available to healthcare professionals, enabling better clinical decisions to be made in the treatment of hypertension. This collaborative approach to patient care can facilitate greater awareness and self-management by patients themselves;

- The reluctance of professionals can be alleviated when conducting research that proves the effectiveness of these applications;

- Doctors are concerned about the increased workload.

- The use of the diet smartphone app by health professionals was seen as a complementary strategy to nutritional counseling. This combination can bring benefits mainly for people with diabetes or obesity, considering that the use of the application favors awareness and self-education about nutrition;

- Using the app proved to be able to increase the intake of healthy foods and reduce the intake of trans fats and consumption of processed meats, which contributes to weight reduction, in addition to encouraging and analyzing users' physical activity. - The use of WeChat technology by nurses is aimed at tia-specific education program, specific training on dementia, which can influence the adoption of changes that facilitate early detection and timely diagnosis of dementia;

- Well-trained nurses can promote health education actions for caregivers of people in condition of dementia; - Conducting short-term training based on WeChat can improve nurses' knowledge and attitude. The use of technology was well accepted by healthcare professionals.

- The use of social media through blogs is aimed at recording information, attendance, monitoring of health care, health promotion and management of health education;

- Communication channels, such as Twitter and PHC blogs, can help in the exchange of information and communication in health. 
Table 1. (cont.)

\begin{tabular}{ll}
\hline Reference (year) & $\begin{array}{l}\text { Article/ Type of study/ Database/ } \\
\text { Level of evidence/ Sample }\end{array}$ \\
\hline Jones et al. ${ }^{\mathbf{3 8}}$ & Investigating the Perceptions of \\
(2018) & Primary Care Dietitians on the Po- \\
& tential for Information Technology \\
& in the Workplace: Qualitative Study \\
& Descriptive exploratory approach \\
& study. \\
& PubMed \\
& Level of Evidence: 3 \\
& Sample: 20 nutritionists
\end{tabular}

Pereira et al. ${ }^{39}$ (2017)

Kolltveit et al. $\mathbf{4 0}$ (2016)

Houghton et al. $\mathbf{4 1}$

(2019)

Mobile application for data collection in health research Applied research of technological production

Scielo

Level of Evidence: 5

Sample: 418 health professionals

Telemedicine in diabetes foot care delivery: health care professionals' experience

Inductive interpretive description. It is part of a cluster-randomized controlled trial

PubMed

Level of Evidence: 2

Sample: 33 participants

Mobilizing Breast Cancer Prevention Research Through Smartphone

\section{Study objective}

Explore the perceptions of PHC nutritionists about the use of information technology in their workplace. Apps: A Systematic Review of the Literature

Systematic review

PubMed

Level of Evidence: 1

Sample: 82 studies

Describe the development of a mobile technology application for data collection in researches about time and movement of health professionals of the Family Health Strategy, in carrying out car interventions/ activities.

Explore the experience of health professionals in the initial phase of the introduction of telemedicine technology in the care of diabetic people with foot ulcers.
Determine how mobile apps are being used for the prevention and control of breast cancer among women around the world.

\section{Conclusions}

- The use of information technologies by nutritionists, such as mobile applications, aims at tracking food intake, administrative technology, patient management systems and the Nutritics system, used for electronic health records;

- Technology considered useful to help clients track their eating behaviors, as well as the progress between appointments;

- They found the lack of time to implement new technologies, lack of information about technologies and resistance to change as a challenges;

- Nutritionists also expressed concern regarding the use of technology by the elderly, a population with greater demand;

- There is easy access to patient information and communication with other professionals.

- The development and use of the DropSync mobile app aims at collecting and managing data;

- The use of the application proved to be an optimized, safe process for recording, storing and sending information. In addition, data collection becomes dynamic, fast, secure and with integrity in the sharing of collected information.

- The use of telemedicine to treat wounds enables communication and discussion of the case;

- Telemedicine users have seen improvements in wound assessment, documentation and records, in addition to communication.

\footnotetext{
- Applications are used for breast cancer prevention, clinical care, healthy lifestyle management and quality of life, as well as to improve medication and assess clinical manifestations, behaviors and risks; - The use of apps to promote tertiary prevention was more prevalent than for secondary and primary prevention.
} 
Table 1. (cont.)

\begin{tabular}{|c|c|c|c|}
\hline Reference (year) & $\begin{array}{l}\text { Article/ Type of study/ Database/ } \\
\text { Level of evidence/ Sample }\end{array}$ & Study objective & Conclusions \\
\hline $\begin{array}{l}\text { Oberg et al. } \mathbf{4 2} \\
(2018)\end{array}$ & $\begin{array}{l}\text { Swedish primary healthcare nurses' } \\
\text { perceptions of using digital eHealth } \\
\text { services in support of patient } \\
\text { selfmanagement } \\
\text { Qualitative descriptive preparatory } \\
\text { study } \\
\text { PubMed } \\
\text { Level of Evidence: } 4 \\
\text { Sample: } 20 \text { nurses }\end{array}$ & $\begin{array}{l}\text { Describe the perceptions of } \\
\text { Swedish PHC nurses regarding } \\
\text { the use of e-Health digital sys- } \\
\text { tems and services to support } \\
\text { patients' self-management. }\end{array}$ & $\begin{array}{l}\text { - The use of e-Health technology is aimed at recording } \\
\text { information and assistance, aiming to support self- } \\
\text { management of patients with chronic diseases; } \\
\text { - Nurses demonstrate that they are against the use of } \\
\text { telemedicine, due to the loss of professional-patient } \\
\text { interaction, in addition to not having sufficient skill to } \\
\text { use this technology; } \\
\text { - Participants claim that the use of the internet will be } \\
\text { increasingly present and there is a need to train profes- } \\
\text { sionals. }\end{array}$ \\
\hline $\begin{array}{l}\text { Banks et al.43 } \\
(2018)\end{array}$ & $\begin{array}{l}\text { Use of an electronic consultation } \\
\text { system in primary care: a qualita- } \\
\text { tive interview study } \\
\text { Qualitative study } \\
\text { PubMed } \\
\text { Level of Evidence: } 5 \\
\text { Sample: } 23 \text { health professionals. }\end{array}$ & $\begin{array}{l}\text { Assess whether an electronic } \\
\text { consultation system improves } \\
\text { staff's ability to manage work- } \\
\text { load and access. }\end{array}$ & $\begin{array}{l}\text { - The use of e-consultation technology has an impact } \\
\text { on the workload of health professionals; } \\
\text { - The team recognized the benefits offered to patients, } \\
\text { including the ability to access the system at any time, } \\
\text { avoiding a busy phone system, and providing an oppor- } \\
\text { tunity to raise undiscussed issues. }\end{array}$ \\
\hline
\end{tabular}

\section{Discussion}

The literature mapping in this scoping review presents a synthesis of studies that address the concept of the use of technologies by PHC professionals in the context of health promotion.

The introduction of technologies in the health system caused the emergence of new concepts, prompting reflection on the potential and limitations of the applicability of these technologies in the daily lives of health professionals and users $\mathbf{2 1 , 2 2}^{2}$. Transversal knowledge in postmodern sociality, induced by the development of interactive media, is considered an original wisdom in which there is collective production of knowledge and common access to it ${ }^{23}$.

Information technologies, such as social networks, represent an increasingly important element of social life ${ }^{\mathbf{2}, 23,24}$, since "a technological culture tends to contaminate the whole of daily life"1(77). Social networks are increasingly being used by PHC health professionals, representing important tools that can be used in favor of health and for health promotion actions.

Social networks, such as Facebook, WhatsApp, Twitter, Instagram and others, are used for communication actions between professionals, clinical or drug consultations, professional development and health promotion $^{8}$. In this scoping review, it was observed that health promotion appeared among the main motivations for the use of applications by professionals, representing $72 \%$ of the selected studies. Others addressed actions to monitor patients ${ }^{25}$, in addition to being a source of communication between professionals ${ }^{26,27}$ or professionals/users ${ }^{28}$, collection of data ${ }^{25,29,30}$ and records ${ }^{29}$.

WhatsApp is the application most used by health professionals, followed by Facebook, as a means of communicating and sharing clinical information, which can pose a risk to the security of patient data ${ }^{8}$. Facebook proved to be a powerful tool for communication and health promotion involving the community in general ${ }^{31}$. 
Community sites of the internet testify to ethics. It is private and, at times, can be immoral, breaking laws, as well as what is socially admitted ${ }^{\mathbf{2 4}}$.

The SmartMove mobile app is intended to promote physical activities. It is an easy-to-use application, which may have contributed positively to user adherence. Smartphone technology, widget, and stage count screen graphics are able to monitor the progress of users in overweight and obese conditions while exercising. The space provided by technology can help healthcare professionals deal with obesity and lifestyle sensitivities. It is necessary for a specific member of the service provider's team to drive the use of the application by other team members ${ }^{32}$.

The DiaCert app can help professionals in the clinical follow-up of patients with type 2 diabetes mellitus, encourage patients to have healthier lifestyle habits and physical practices, allow patients to share their personal data with their professional, receive information related to hemoglobin glycated, directly from the health system to the smartphone ${ }^{33}$.

The use of cell phone applications or blood pressure monitors by patients may have the potential to increase the amount of blood pressure data available to healthcare professionals, provided that the quality of this data is ensured for clinical decision-making in the treatment of systemic arterial hypertension. This approach can also facilitate greater awareness and self-care on the part of patients, taking into account that technology allows the patient to be able to visualize, with greater clarity, the effect and importance of changing lifestyles and the antihypertensives drugs ${ }^{34}$.

The social mutation caused by postmodernity brings into force the need for a transmutation of language ${ }^{23}$. Carrying out health interventions, using a combination of nutritional counseling and a diet application, proved to be more efficient than when the health professional performs only isolated counseling. The complementary use of this tool proved to be able to improve users' adherence to both healthier eating and physical activity practices ${ }^{35}$.

The use of technological bases such as the web, cell phones or computers, by health professionals, to promote change in behavior related to alcohol had a positive effect, considering that it can reduce its consumption and/or subsequent damage. The use of these technologies showed that the degree to which patients and professionals considered digital interventions acceptable, viable and sustainable can influence the effectiveness of interventions ${ }^{5}$.

WeChat, used to receive short-term training on dementia, such as lectures, video sharing and group discussions, has influenced changes in professionals' behavior. The acquisition of knowledge about risk factors to which people are susceptible can increase early detection, referral to specialized centers, the quality of care and treatment offered to patients and caregivers, as well as encourage professionals to promote educational actions in health ${ }^{36}$.

The use of blogs was a qualitative leap in communication between health professionals working in PHC, as it allowed for debate and participation between them. The introduction of this technology can also improve the dialogue/interaction between professionals and patients, thus promoting person-centered care ${ }^{21}$. It is noted that, through the use of communication sites such as blogs, it is possible to share common emotions ${ }^{23}$, in addition to making it possible to carry out the dissemination of health information, covering other areas, such as case monitoring and health promotion ${ }^{37}$. By empowering patients through education, they can participate in decision-making regarding their health status and promoting it21.

Information technologies allow professional/user interaction outside of formal consultation, improve communication and information sharing between professionals in order to achieve better health outcomes, access to information to support education and interventions, as well as tracking digital. The 
use of the Nutritics app, by nutritionists, for tracking food intake, administrative technology, patient management and data analysis systems, electronic health records and consultations, proved to be effective in promoting diet control and healthy eating. Tracking food intake can help empower patients and achieve better results ${ }^{\mathbf{3 8}}$.

The development and use of the DropSync mobile application allows the collection and management of data, optimizing the process of recording and storing, sending and analyzing selected information ${ }^{39}$.

The use of mobile technology (tablets) by Community Health Agents (ACS) in Brazil is aimed at recording data, filling out forms used in the daily life of the ACS, not evidencing health promotion actions. The low previous experience with Information and Communication Technology (ICT) does not represent an impediment to the use of the tablet. Weaknesses include the difficulty of simultaneous manual and computerized records and the relative delay in transmitting the collected data. Such weaknesses may result in the minimization of part of the expected benefits from the use of the tablet ${ }^{30}$.

Telemedicine for wound treatment optimizes communication between health professionals in PHC and outpatient clinics, enabling the use of images and their description, discussion and reflection on the treatment and improvement in the quality of records ${ }^{40}$.

Breast cancer prevention apps can be used for early detection and early treatment $\mathbf{4 1}^{\mathbf{4}}$. Support services for the self-management of people with chronic conditions, through the use of e-Health telemedicine, have been adopted in the daily lives of professionals ${ }^{42}$. In addition, they support and monitor changes in health behavior for better control of chronic disease and patients proactivity in self-care/self-management activities ${ }^{\mathbf{4 1}}$.

The online consultation support technology, called e-consultation, has shown effectiveness. It allows adjustment notes, such as renewal of medication prescriptions and evaluation of test results, despite the possible work overload due to the use of the telephone for electronic consultations ${ }^{\mathbf{4 3}}$. Nursing professionals show the difficulty of adapting to the use of e-Saúde technology, as they do not feel safe, in addition to the fear of not being able to interact with patients in a satisfactory manner ${ }^{\mathbf{2}}$.

It is likely that the reluctance of health professionals to use new technologies is related to the nature and reliability of the data provided, in addition to the concern with the increased workload and responsibility over the data ${ }^{34}$. "Here is the existing difficulty in apprehending the nascent post-modernity. In reducing the dense and complex real to a measurable reality"23(4). This can be overcome with evidence that demonstrates efficacy and cost-effectiveness results. Health regulatory bodies can play an important role in quality control and in providing explicit guidelines regarding the implementation of new technologies in health ${ }^{34}$.

Promoting a healthy lifestyle is still a challenge, but it can be of positive coping. For professionals to be able to effectively achieve health promotion using tools and technologies, it is necessary that they are professionally trained and use evidence-based practices to achieve the goals in view of the needs of each one ${ }^{7}$. Thus, the renewed social forms need to respond to the rethought intellectual forms ${ }^{\mathbf{1}}$. It is important to maintain a balanced view of digital interventions, so that these technologies are used as a complement, that is, they do not replace face-to-face meetings between health professionals and patients ${ }^{7}$.

It is noted that health promotion is a transversal articulation strategy, which aims to break with the excessive fragmentation in the approach of the health-illness process and reduce vulnerability, risks and damages that occur in it ${ }^{9}$. Technologies can be used by health professionals to achieve these ends ${ }^{\mathbf{4 1}}$, as technologies represent the beating heart of postmodern society'1. 
All studies that are part of this review have their limitations. This scoping review had as a limitation the sample reduced by the temporal definition of collection, between 2016-2019, justified by the civil framework of the internet in Brazil and its regulation only in 2016. It presents as a contribution the synthesis of knowledge produced by a sample composed of studies from different geographic regions of the world, which address the use and the need to implement technologies in PHC to promote the health of people/families.

\section{Conclusions}

The mapping of available evidence regarding the concept 'use of technologies' by PHC professionals in the context of health promotion brought results that impact health conditions and promote healthier life choices.

Technologies are part of the daily lives of professionals, demonstrating effectiveness in actions to promote health and a healthier lifestyle, such as diet, physical activity and change of behaviors related to alcohol. Its use also includes health control measures, curatives and medications. In addition, it is a source of communication between professionals, professionals and users of PHC, contributing to professional development, characterized as innovative tools.
New strategies for implementing technologies in $\mathrm{PHC}$ are possible, with professional training and motivation, in order to ensure greater effectiveness and quality in care and health promotion for people/families.

\section{Collaborators}

Silva TC (0000-0002-2980-8973)* and Carvalho AG (0000-0001-8099-6829)* contributed to data collection, data interpretation, manuscript writing and approval of the final version, responsibility for all aspects of the work in ensuring the accuracy and completeness of any part of the work. Tholl AD (0000-0002-5084-9972)*, Borrego MAR (0000-0002-5677-0165)* and Soto PJL (00000002-1046-6686)* contributed equally to the critical review of the intellectual content and approval of the final version, responsibility for all aspects of the work in ensuring the accuracy and completeness of any part of the work. Viegas SMF (0000-0002-0287-4997)* contributed to the conception and design of the study, review of data collection, data interpretation, writing of the manuscript and approval of the final version, responsibility for all aspects of the work under warranty the accuracy and completeness of any part of the work. 


\section{References}

1. Maffesoli M. A ordem das coisas: pensar a pós-modernidade. Rio de Janeiro: Forense; 2016.

2. Maffesoli M. A república dos bons sentimentos. São Paulo: Iluminuras: Itaú Cultural; 2009.

3. Maffesoli M. Arcaísmo, cibercultura e reencantamento do mundo: as dobras do cotidiano tecnológico. Comunicação e Informação. 2018 [acesso em 2020 abr 29]; 21(02):04-18. Disponível em: https:// doi.org/10.22478/ufpb.1981-0695.2019v14n1.44401.

4. Brasil. Lei $\mathrm{n}^{\circ} 12.965$, de 23 de abril de 2014. Estabelece princípios, garantias, direitos e deveres para o uso da internet no Brasil. Diário Oficial da União. 24 Abr 2014.

5. Ramsey AT, Satterfield JM, Gerke DR, et al. Technology-Based Alcohol Interventions in Primary Care: Systematic Review. Journ al of Medical Internet Research. 2019 [acesso em 2020 abr 29]; 21(04):12. Disponível em: https://doi.org/10.2196/10859.

6. Jong CC, Ros WJG, Leeuwen MV, et al. The challenge of involving elderly patients in primary care using an electronic communication tool with their professionals: a mixed methods study. Journal of Innovation in Health Informatics. 2017 [acesso em 2020 abr 30]; 24(3):275-283. Disponível em: http://dx.doi. org/10.14236/jhi.v24i3.937.

7. Berman AH, Kolaas K, Petersén E, et al. Clinician experiences of healthy lifestyle promotion and perceptions of digital interventions as complementary tools for lifestyle behavior change in primary care. BMC Family Practice. 2018 [acesso em 2020 mar 5]; 19(139):01-11. Disponível em: https://doi.org/10.1186/ s12875-018-0829-z.

8. Marin-Gomez FX, Cuyas FG, Reig-Bolano R, et al. Social Networking App Use Among Primary Health Care Professionals: Web-Based Cross-Sectional Survey. JMIR mHealth and uHealth. 2018 [acesso em 2020 abr 30]; 06(12):12. Disponível em: https:// doi.org/10.2196/11147.
9. Brasil. Portaria de Consolidação n ${ }^{\circ} 2$, de 28 de setembro de 2017. Consolida as normas sobre as políticas nacionais de saúde do SUS. Diário Oficial da União. 28 Nov 2017.

10. Tricco AC, Lillie E, Zarin W, et al. PRISMA Extension for Scoping Reviews (PRISMA-ScR): checklist and Explanation. Annals of Internal Medicine. 2018 [acesso em 2020 jan 5]; 169(07):467-73. Disponível em: https://doi.org/10.7326/m18-0850.

11. Daudt HML, Van Mossel C, Scott SJ. Enhancing the scoping study methodology: a large, inter-professional team's experience with Arksey and O'Malley's framework. BMC Medical Research Methodology. 2013 [acesso em 2020 abr 5]; 13(48):01-09. Disponível em: http://dx.doi.org/10.1186/1471-2288-13-48.

12. Arksey H, O'Malley L. Scoping studies: towards a methodological framework. International Journal of Social Research Methodology. 2005 [acesso em 2020 fev 25]; 08(01):19-32. Disponível em: https://doi.org/ $10.1080 / 1364557032000119616$

13. Aromataris E, Munn Z, editores. JBI Manual for Evidence Synthesis. C. s.: JBI; 2020. [acesso em 2021 set 5]. Disponível em: https://wiki.jbi.global/display/MANUAL/Downloadable+PDF+-+current+version?prev iew=/61636614/67733014/JBIMES_2020August.pdf.

14. Guyatt GH, Oxman AD, Visit GE, et al. GRADE: an emerging consensus on rating quality of evidence and strength of recommendations. Journal BMJ. 2008 [acesso em 2020 abr 5]; 336(7650):924-926. Disponível em: https:// doi.org/10.1136/bmj.39489.470347.AD.

15. Brasil. Decreto $n^{\circ} 8.771$, de 11 de maio de 2016. Regulamenta a Lei $\mathrm{n}^{\circ} 12.965$, de 23 de abril de 2014 para tratar das hipóteses admitidas de discriminação de pacotes de dados na internet e de degradação de tráfego, indicar procedimentos para guarda e proteção de dados por provedores de conexão e de aplicações, apontar medidas de transparência na requisição de dados cadastrais pela administração pública e estabelecer parâmetros para fiscalização e apuração de infrações. Diário Oficial da União. 11 Maio 2016. 
16. Bennett S, Bennett JW. The process of evidence-based practice in occupational therapy: informing clinical decisions. Australian Occupational Therapy Journal. 2000 [acesso em 2020 mar 10]; 47(01):17180. Disponível em: https://doi.org/10.1046/j.14401630.2000.00237.x.

17. Sampaio RF, Mancini MC. Systematic review studies: A guide for careful synthesis of the scientific evidence. Revista Brasileira de Fisioterapia. 2007 [acesso em 2020 mar 10]; 11(01):83-89. Disponível em: https:// doi.org/10.1590/S1413-35552007000100013.

18. Sackett DL, Straus SE, Richardson WS, et al. Evidence-based medicine: How to practice and teach EBM. 2. ed. Edinburgh: Churchill Livingstone; 1996.

19. Stetler CB, Brunell M, Giuliano KK, et al. Evidence-based practice and the role of nursing leadership. Journal of Nursing Administration. 1998 [acesso em 2020 mar 15]; 28(07-08):45-53. Disponível em: https://doi.org/10.1097/00005110-199807000-00011.

20. Gray MJA. Evidence based healthcare: how to make health policy and management decision. Edinburgh: Churchill Livingstone; 1997.

21. Oliver-Mora M, Iñiguez-Rueda L. El uso de las tecnologías de la información y la comunicación (TIC) en los centros de salud: la visión de los profesionales en Cataluña, España. Revista Interface. 2017 [acesso em 2020 mar 5]; 21(63):945-955. Disponível em: https://doi.org/10.1590/1807-57622016.0331.

22. Plessis LM, Koornhof HE, Marais ML, et al. Implementation of the Road-to-Health-Booklet health promotion messages at primary health care facilities, Western Cape Province, South Africa Western Cape Province, South Africa. South African journal of child health. 2017 [acesso em 2020 fev 10]; 11(04):164-169. Disponível em: http:// www.scielo.org.za/pdf/sajch/vlln4/09.pdf.

23. Maffesoli M. O tempo retorna: formas elementares da pós-modernidade. Rio de Janeiro: Forense Universitária; 2012.

24. Maffesoli M. Pactos emocionais: reflexões em torno da moral, da ética e da deontologia. Curitiba: PUCPRESS; 2018.

25. Mastellos N, Bliźniuk G, Czopnik D, et al. Feasibility and acceptability of TRANSFoRm to improve clinical trial recruitment in primary care. Family Practice. 2016 [acesso em $2020 \mathrm{fev} 20$ ]; 33(02):186-191. Disponivel em: https://doi.org/10.1093/fampra/cmv102.

26. Lofters AK, Slater MB, Angl EN, et al. Facebook as a tool for communication, collaboration, and informal knowledge exchange among members of a multisite family health team. Journal of Multidisciplinary Healthcare. 2016 [acesso em 2020 mar 20]; 25(9):29-34. Disponível em: https://doi.org/10.2147/JMDH.S94676.

27. Keyworth C, Hart J, Armitage CJ, et al. What maximizes the effectiveness and implementation of technology-based interventions to support healthcare professional practice? A systematic literature review. BMC Medical Informatics and Decision Making. 2018 [acesso em 2020 mar 15]; 18(93):21. Disponível em: https://doi.org/10.1186/s12911-018-0661-3.

28. Smailhodzic E, Hooijsma W, Boonstra A, et al. Social media use in healthcare: A systematic review of effects on patients and on their relationship with healthcare professionals. BMC Health Services Research. 2016 [acesso em 2020 abr 15]; 16(442):14. Disponível em: https://bmchealthservres.biomedcentral. com/articles/10.1186/s12913-016-1691-0.

29. Cavalcante RB, Silva HRM, Silva TIM, et al. Diffusion of the technological innovation e-sus ab: acceptance or rejection? Cogitare Enfermagem. 2018 [acesso em 2020 abr 15]; 23(3):01-13. Disponível em: https:// dx.doi.org/10.5380/ce.v23i3.55911.

30. Daltro EFMA, Barbosa DSJ, Machado APR, et al. Aceitação e uso de tecnologias móveis de informação pelos agentes comunitários de saúde de Sapeaçu. Revista Baiana de Saúde Pública. 2017 [acesso em 2020 abr 2]; 41(02):324-333. Disponível em: https:// doi.org/10.22278/2318-2660.2017.v41.n2.a1333.

31. Bernardes VP, Dias LF, Pereira MA, et al. Facebook como Ferramenta Pedagógica em Saúde Coletiva: In- 
tegrando Formação Médica e Educação em Saúde. Revista Brasileira de Educação Médica. 2019 [acesso em 2020 abr 3]; 43(01):652-661. Disponível em: http://dx.doi.org/10.1590/1981-5271v43suplementol-20190192.

32. Glynn LG, Glynn F, Casey M, et al. Implementation of the SMART MOVE intervention in primary care: a qualitative study using normalisation process theory. BMC Family Practice, United Kingdom. 2018 [acesso em 2020 abr 15]; 19(48):10. Disponível em: https://doi.org/10.1186/s12875-018-0737-2.

33. Bonn SE, Alexandrou C, Steiner KH, et al. App-technology to increase physical activity among patients with diabetes type 2 - the DiaCert-study, a randomized controlled trial. BMC Public Health. 2018 [acesso em 2020 mar 5]; 18(119):01-07. Disponível em: https://doi.org/10.1186/s12889-018-5026-4.

34. Morrissey EC, Glynn LG, Casey M, et al. New self-management technologies for the treatment of hypertension: general practitioners' perspectives. Family Practice. 2018 [acesso em 2020 abr 5]; 35(03):318-322. Disponível em: https://doi.org/10.1093/fampra/cmx100.

35. Recio-Rodriguez JI, Conde CA, Calvo-Aponte MJ, et al. The Effectiveness of a Smartphone Application on Modifying the Intakes of Macro and Micronutrients in Primary Care: A Randomized Controlled Trial. The EVIDENT II Study. Nutrients, Switzerland. 2018 [acesso em 2020 abr 5]; 10(10):16. Disponível em: https://doi.org/10.3390/nu10101473.

36. Wang F, Xião LD, Wang K, et al. Evaluation of a WeChat-based dementia-specific training program for nurses in primary care settings: A randomized controlled trial. Applied Nursing Research, Philadelphia. 2017 [acesso em 2020 abr 10]; 38(01):51-59. Disponível em: https://doi.org/10.1016/j.apnr.2017.09.008.

37. Pinto LF, Rocha CMF. Innovations in Primary Health care: the use of communications technology and information tools to support local management. Ciênc. Saúde Colet. 2016 [acesso em 2020 mar 2]; 21(05):1433-1448. Disponível em: https://doi. org/10.1590/1413-81232015215.26662015.
38. Jones A, Mitchell LJ, O'Connor R, et al. Investigating the Perceptions of Primary Care Dietitians on the Potential for Information Technology in the Workplace: Qualitative Study. Journal of Medical Internet Research. 2018 [acesso em 2020 abr 10]; 20(10):27. Disponível em: https://doi.org/10.2196/jmir.9568.

39. Pereira IM, Bonfim D, Peres HHC, et al. Mobile application for data collection in health research. Acta Paulista de Enfermagem. 2017 [acesso em 2020 abr 2]; 30(5):479-488. Disponível em: https://doi. org/10.1590/1982-0194201700069.

40. Kolltveit BCH, Gjengedal E, Graue M, et al. Telemedicine in diabetes foot care delivery: health care professionals' experience. BMC Health Services Research. 2016 [acesso em 2020 mar 10]; 16(134):08. Disponível em: https://doi.org/10.1186/s12913-016-1377-7.

41. Houghton LC, Howland RE, Mcdonald JA. Mobilizing Breast Cancer Prevention Research Through Smartphone Apps: A Systematic Review of the Literature. Mobilizing Breast Cancer Prevention Research. 2019 [acesso em 2020 mar 2]; 07(01):15. Disponível em: https://doi.org/10.3389/fpubh.2019.00298.

42. Oberg U, Orre CJ, Isaksson U, et al. Swedish primary healthcare nurses' perceptions of using digital eHealth services in support of patient self management. Scandinavian Journal of Caring Sciences, 2018 [acesso em 2020 abr 30]; 32(2):961-970. Disponível em: https://onlinelibrary.wiley.com/doi/10.1111/scs.12534.

43. Banks J, Farr M, Salisbury C, et al. Use of an electronic consultation system in primary care: a qualitative interview study. British Journal of General Practice, Londres. 2018 [acesso em 2020 abr 29]; 68(666):01-08. Disponível em: https://doi. org/10.3399/bjgp17X693509.

Received on $02 / 14 / 2021$

Approved on 10/09/2021

Conflict of interests: non-existent

Financial support: Masters Scholarship of the Coordination for the Improvement of Higher Education Personnel (Capes), Process: 88887.494064/2020-00 